This PDF is a selection from an out-of-print volume from the National Bureau of Economic Research

Volume Title: Risk Aspects of Investment-Based Social Security Reform Volume Author/Editor: John Y. Campbell and Martin Feldstein, editors Volume Publisher: University of Chicago Press

Volume ISBN: 0-226-09255-0

Volume URL: http://www.nber.org/books/camp01-1

Publication Date: January 2001

Chapter Title: The Effect of Pay-When-Needed Benefit Guarantees on the Impact of Social Security Privatization

Chapter Author: Kent Smetters

Chapter URL: http://www.nber.org/chapters/c10592

Chapter pages in book: (p. 91 - 112) 


\section{The Effect of Pay-When-Needed Benefit Guarantees on the Impact of Social Security Privatization}

Kent Smetters

\subsection{Introduction}

Many plans to privatize the mostly unfunded U.S. social security defined-benefit program implicitly contain unfunded obligations of their own in the form of benefit guarantees. One example is the promise that the assets in the new private accounts will produce an annuitized retirement benefit at least equal to what the participant would have received under social security. The recent proposal by Senator Phil Gramm (1998), for example, would guarantee that workers receive an annuitized benefit equal to 100 percent of what they would have received under social security plus 20 percent of the value of the investment they build up "over their working lives." Unless the government reneges on this promise, future workers would have to be taxed on a pay-when-needed basis to make up for shortfalls. A minimum-benefit guarantee, therefore, represents an unfunded obligation that must be priced since money is not set aside ahead of time to cover the associated actuarial burden.

This paper uses a simplified version of the model presented in Smetters (1998) to report that large pay-when-needed minimum-benefit guarantees can be very costly, so costly that they can undermine and possibly reverse the salutary economic effects traditionally associated with privatization. If payroll taxes were increased over time (from 12.4 to 18.75 percent) to satisfy present-law benefits, privatization would reduce unfunded liabilities by more than a third only if the government guaranteed a benefit level

Kent Smetters is assistant professor of insurance and risk management at the Wharton School, University of Pennsylvania.

The author has benefited on numerous occasions from conversations with Zvi Bodie, Henning Bohn, Peter Diamond, and Martin Feldstein on earlier and related work. John Campbell and David Wilcox provided helpful comments. 
below that currently provided by social security. This is true even though the expected privatized benefit is as much as five times as large as the benefit provided under social security. The reduction in unfunded liabilities is small even at a high contribution rate because the returns to all the dollars in the private account are perfectly correlated. To be sure, investing more dollars reduces the work that each dollar must do in order for the sum of dollars in the account at retirement to exceed the minimum-benefit guarantee. But the government must insure more dollars at a high contribution rate. So each dollar is being insured less, but more dollars are being insured, with only a small net effect on unfunded liabilities. The net liability decreases very little because insurance against very low equity returns is extremely valuable; the guaranteed value, therefore, decreases slowly in the total number of dollars invested. An alternative to a small pay-whenneeded guarantee is to prefund it with a tax from current workers to future workers, which transfers resources in the opposite direction as standard pay-as-you-go financing.

\subsubsection{Two Percent Accounts}

To be sure, the high average historical real rate of return to equities makes replacing social security with private accounts seem almost painless. To maintain present-law benefits, social security taxes would eventually have to increase to 18.75 percent of payroll, up from 12.4 percent today. Privatizers argue that a small tax would suffice if it were invested in equities. This tax could be as low as 2 percent of payroll- the popular " 2 percent accounts." 1 The only cost of this reform would be that some workers would have to pay the 2 percent tax on top of the payroll tax. But, in return, future workers will be helped by the smaller overall tax.

The expected small tax rate in a new privatized system is due to what Paul Samuelson once referred to as the "eighth wonder of the world": compound interest. Small differences in annual rates of return between competing saving vehicles add up to big money over many years. The intrinsic average rate of return to a mature social security system like ours equals the growth rate of the payroll-tax base. This is because payroll taxes are not invested in capital but instead mostly paid out immediately as benefits (so-called pay-as-you-go financing). This growth rate has averaged about 2 percent per year after inflation since the early 1970s and is expected to average closer to 1.1 percent per year in the future. Some analysts use an average return to stocks of about 9 percent, which includes roughly 7 percent return to equities and about 2 percent from taxes paid by corporations. Over a thirty-year saving horizon, typical for the average worker, $\$ 2$ invested at 9 percent will return about the same final benefit as $\$ 18.75$ invested at 1.1 percent.

1. The " 2 percent" accounts were popularized by Feldstein and Samwick (1997) and have been examined as well in Shipman (1998). 
But most of the tax saving that appears to come from equity investment comes from attempting to exploit the historical wedge between Treasury bonds and equities - the "equity premium." Empirically, private investors have demanded a considerable premium to accept risky investments. The return to equities above U.S. government bonds during the past century has averaged an astronomical six hundred basis points. Traditionally, this premium has been regarded as compensation for risk. Subtracting this premium from the 9 percent private market return substantially reduces the power of compound interest. At a 3 percent real annual return, the replacement-tax rate would increase from 2 to 12 percent.

To be sure, the equity premium has been a puzzle because it is higher than can be explained by compensation for risk inside the standard neoclassical infinite-horizon model with isoelastic utility. ${ }^{2}$ The fact that the equity premium is a puzzle, however, does not mean that it represents "found money." The government can exploit the premium only if the government somehow improves market efficiency. If the government fails to improve the functioning of markets, then the equity-premium puzzle simply reflects the ignorance of economists regarding their understanding of attitudes toward risk. The puzzle does not present a costless exploitable opportunity.

\subsubsection{The Risk in Stocks over Long Periods}

Privatizing social security would subject a greater amount of retirement saving to market risk by moving to a system of personal accounts invested in the capital market. Equity risk is no small matter even over long horizons. Indeed, there have been fifteen years in this century alone in which the real value of the U.S. stock market fell over 40 percent in the succeeding decade. ${ }^{3}$ Moreover, some economists believe that the market might fall another 40 percent or more during the next ten years owing to mean reversion. ${ }^{4}$

While it is sometimes believed that stocks have little risk over the "long run," this view is not shared by many finance economists. ${ }^{5}$ Jagannathan and Kocherlakota (1996), for example, have shown that, even for a fortyyear holding period in which stocks outperform bonds with almost 100 percent certainty, the optimal portfolio consists of 60 percent bonds and 40 percent stocks for a person with a reasonable aversion to risk.

2. Mehra and Prescott (1985). Kocherlakota (1996) provides an excellent literature review.

3 . These include 1908-12, 1937, 1939, 1965-66, and 1968-73. Not all drops, however, have been sudden. The stock market declined by about 50 percent in real value between 1973 and 1975 and did not return to its pre-1973 level for almost ten years. Shiller (1996) provides an overview of market risk.

4. Campbell and Shiller (1998) argue that, contrary to the efficient market hypothesis, the price-dividend ratio is a powerful predictor of future prices. They predict a 38 percent loss in the real value of stocks over the next decade.

5. See, e.g., Bodie's (1995) extensive examination of the long-run risks associated with stocks. 
The large long-run averages in the United States may be misleading for other reasons as well. First, while the U.S. market has performed well during the past century, the same has not been true for major foreign markets, which have rendered an average return of only 1.5 percent after inflation (Goetzmann and Jorion 1996). Various social security reforms might necessitate investments abroad in order to diversify across a larger capital base. Second, calculations that assume a 9 percent real return to equities also ignore the portfolio substitutions that would occur as people might reduce their other holdings of risky assets. These portfolio shifts would tend to reduce both the capital income-tax revenue received by the government and the returns that agents would receive in the rest of their portfolio. Third, using a fixed rate also ignores the fact that a larger capital stock would tend to lower interest rates.

\subsubsection{Analysis of Guarantees}

At least two approaches have been used to evaluate minimum-benefit guarantees in the context of social security. One method, which I will loosely call the likelihood method, uses Monte Carlo simulation based on the historical experience of bonds and equities to predict the likelihood that the assets in the new private accounts fail to replace the benefit provided under social security (Hieger and Shipman 1997; Feldstein, Ranguelova, and Samwick, chap. 2 in this volume). The second method uses arbitrage-pricing theory and assumes that the observable price covariances reflect underlying preferences (Smetters 1998). ${ }^{6}$ Both approaches assume similar price moments based on similar historical data. And both approaches report marginal calculations by assuming fixed price moments; that is, they correspond to privatizing a single dollar's worth of social security benefits.

Despite their commonalities, the two approaches can paint strikingly different pictures of the cost of the benefit guarantees. Although the likelihood method does not explicitly calculate the price of a benefit guarantee, it often suggests little cost. ${ }^{7}$ For example, Hieger and Shipman argue that, for a contribution rate at today's level, the new private accounts will fail to replace the benefit level provided under social security with only a very small probability. They do not, however, consider the transition from pay-

6. Bodie (chap. 8 in this volume) and Marcus (1987) have examined guarantees in related settings. Merton (1998) provides an extensive review of the use of option pricing in evaluating guarantees and numerous other policies.

7. An important exception is Bodie and Crane (1998), which considers a hypothetical worker who retires at age sixty-five, earned $\$ 50,000$ in the final year of employment, and has an asset target of $\$ 446,000$ at age sixty-five to provide a twenty-year stream of $\$ 30,000$ on a real basis. Bodie and Crane show that, although new financial products can play an important role as investment alternatives in defined-contribution plans, a nontrivial amount of risk still remains. In particular, over 10 percent of the population fails to meet the target. For the importance of risk over long horizons, see also Bodie (1995). 
as-you-go financing to funding. Feldstein, Ranguelova, and Samwick (chap. 2 in this volume) consider the transition, and their analysis recognizes that the historical data represent draws from an underlying distribution that can include shocks not yet observed. They show that using a contribution rate less than half of today's value will, with a very high probability, lead to benefits that exceed those provided under social security.

In sharp contrast, arbitrage pricing suggests that the unfunded guarantee to replace social security benefits is quite costly. Replacing one unfunded pay-as-you-go benefit with a pay-as-you-go guarantee can lead to only a small net reduction in unfunded liabilities and possibly even an increase (Smetters 1998; see below). Indeed, replacing a fixed defined benefit with a minimum benefit of the same value is in effect a benefit increase.

Both methods give correct but different information. The likelihood method stresses the modest amount of large persistent shocks in the historical data. By utility adjusting these loss probabilities, the arbitrage approach stresses the high aversion, as reflected in observable price moments, to the infrequent but large shocks, including potential shocks that have yet to be observed.

\subsubsection{Limits of the Present Analysis}

This paper estimates the reduction in unfunded liabilities following privatization in the presence of a benefit guarantee. In doing so, it makes several assumptions that, on being relaxed, could lead to different results. I am relaxing several of these assumptions in work in progress. The computations reported here, like those of any stylized model, should be viewed with caution.

\section{Complete Markets}

One key assumption made in this paper is that the actuarial benefit of a minimum benefit to generation $t$ is equal to the actuarial cost imposed on generation $t+1$. Option pricing, pioneered by Black and Scholes (1973) and Merton (1973), is used to calculate the value of the benefit guarantee. (A general formulation of arbitrage pricing is given in Ross [1976].) This allows for calculating the value of a guarantee without resorting to approximations. Option-pricing technology also takes risk into account instead of focusing on mean paths. The calculations presented here correspond to what is commonly known as the complete markets benchmark, which precludes any possible arbitrage possibility on the part of the government.

In reality, markets are, of course, incomplete in numerous ways. One source of market incompleteness stems from the legal prohibition of leaving negative bequests to future generations. This legal constraint prevents generation $t$ private agents from negotiating risk-sharing deals on the be- 
half of future generation $t+1$ agents. The government can overcome this limitation by precommitting future generations. ${ }^{8}$

The actuarial value of a benefit guarantee to one generation might, therefore, be less than or greater than the actuarial cost to the next generation once incomplete markets are taken into account. ${ }^{9}$ The exact answer depends, in part, on the correlation of stock returns to generation $t$ with the wages of generation $t+1$. A tax on generation $t+1$ is more costly to them if their wages decline at the same time. The standard assumption is that productivity is the only source of uncertainty, which, in turn, implies perfect correlation. In this case, the methodology used in this paper generally underprices the cost of the minimum-benefit guarantee to generation $t+1$, so the already high cost of guarantees estimated here is understated. Allowing for enough imperfect correlation can shift the calculations in the other direction. Empirically, wages and stock returns appear to be highly correlated at generational frequencies. But the lack of unique long-run period averages implies that the confidence interval includes virtually all values between zero correlation and perfect correlation. The approach taken here, therefore, seems like a useful benchmark, at least until more centuries of data become available.

\section{Marginal Analysis}

All computations ignore general equilibrium effects on prices and, therefore, correspond to only a small move toward privatization. In particular, the paper reports the change in unfunded liabilities associated with privatizing a single dollar's worth of social security benefit. The property of risk aversion implies that the marginal cost of guarantee to generation $t+1$ increases with the absolute size of the guarantee. The focus on marginal analysis, therefore, leads to an underestimate of the cost of the guarantee per dollar guaranteed.

\section{Moral Hazard}

The paper ignores two moral hazard issues that could lead to more expensive guarantees. First, it assumes that equity investment is restricted to a broad index, such as the S\&P500. Allowing for more choice would tend to increase the cost of a minimum-benefit guarantee because those whose benefit is near the guarantee level would have the incentive to "go for broke." The paper also assumes that private accounts are "locked boxed" until retirement. Allowing for some early withdrawals, perhaps during a recession, could increase the cost of the guarantee.

8. This issue has been examined in the context of social security by Merton (1983) and Bohn (1998).

9. Even if the government can create wealth by completing a missing market, arbitrage pricing still gives the opportunity cost of using found money for a particular purpose. Found money can be spent numerous ways in a world with highly substitutable policy instruments. 


\section{Imputed Option Prices}

Because options for broad stock indices are not available with generational frequency maturity dates, the analysis presented here imputes the cost of option prices using the Black-Scholes option-pricing formula. This approach might underprice the cost of a guarantee since the options on broad indices that are traded are generally more expensive than the BlackScholes formula predicts given the variance of historical returns.

\section{Political Uncertainty and Information}

This paper ignores political uncertainty and information issues. Both these issues are likely to be considerably important. And both challenge the basic assumption inside the D.C. Beltway that contends that any viable move toward personalized accounts must incorporate a minimum benefit equal to what people would have received under social security.

Most Latin American countries, with the exception of Mexico, promise a minimum benefit that is smaller, as a fraction of average preretirement income, than the average benefit provided by the U.S. social security system. The minimum benefit in the much-touted Chilean reform, for example, equals only about 25 percent of average wages (Diamond and Valdés-Prieto 1994). Mitchell and Barreto (1997) show that these plans are quite popular and that this popularity has less to do with economics than with perception and politics. This popularity includes seeing money accumulate in one's own individual account and out of the hands of the government. Americans might be different than Chileans in both personality and history. But few Americans view their future social security benefits free from political uncertainty either. To the extent that this political uncertainty inflates people's discount rate, privatization can exploit a genuine arbitrage possibility, provided that policy makers do not, in turn, create significant uncertainty about how the new private accounts are taxed.

Privatization can also alter perceived net tax rates. The net social security tax rate for the main household earner is generally less than the statutory rate because the additional tax paid with an extra dollar of wages corresponds to an increase in future benefits. Social security commingles old-age insurance and redistribution, which makes calculating net tax rates difficult, thereby distorting labor supply. Reducing this complexity could result in sizable improvements to economic efficiency and welfare.

\subsection{Pricing a Minimum-Benefit Guarantee}

This section outlines the model used and the stylized privatization reform. Both the stylized reform and the model are similar in spirit to those analyzed in the important work of Feldstein and Samwick (1997) and of 
Feldstein, Ranguelova, and Samwick (chap. 2 in this volume). The transition toward privatization is accomplished with a simple add-on tax. Following their lead, the model presented here assumes that stocks are risky but that wages and the return to social security are not. ${ }^{10}$

\subsubsection{Model}

Life-cycle agents live for two periods, and their lifetime utility is given by

$$
E\left\{\sum_{j=1}^{2} \lambda^{j} U\left(C_{j, t}\right) \mid t\right\}
$$

where $C_{j, t}$ is the consumption in year $j$ by the generation $t$ agent, and $\lambda$ is the discount factor. The generation $t$ agent earns a labor income equal to $Y_{1}$ at age 1 , consumes $C_{1, t}$ at age 1 , and saves the difference in either equities that pay a risky rate of return equal to $e_{t}$ during period $t$ or a risk-free bond that pays $r$. It is assumed that the stock process can be described by an Itō-type stochastic differential equation and, without loss in generality, has a stationary expected yield $\bar{e} \equiv E\left(e_{t} \mid t\right)$. The individual faces a social security payroll tax equal to $\tau$, the proceeds of which are invested in a payas-you-go social security asset that pays a rate of return equal to $g$. The individual in period 2, therefore, has realized assets equal to

$$
\begin{aligned}
A_{2, t}= & {\left[(1-\tau) Y_{1}-C_{1, t}\right] \cdot\left[(1+r) \alpha+\left(1+e_{t}\right)(1-\alpha)\right] } \\
& +\tau Y_{1}(1+g),
\end{aligned}
$$

where $\alpha(0 \leq \alpha \leq 1)$ is the share of private assets invested in bonds, and $(1-\alpha)$ is the share of assets invested in equities. Time subscripts for these portfolio-share variables are omitted. The first-order conditions are standard:

$$
\begin{aligned}
& U^{\prime}\left(C_{1, t}\right)=\lambda\left(1+r_{t}\right) E\left[U^{\prime}\left(C_{2, t}\right) \mid t\right], \\
& U^{\prime}\left(C_{1, t}\right)=\lambda E\left[\left(1+e_{t}\right) U^{\prime}\left(C_{2, t}\right) \mid t\right] .
\end{aligned}
$$

Note that, for linear utility (risk neutrality), these equations imply $r=\bar{e}$ $\equiv E\left(e_{t} \mid t\right)$, that is, that the expected rate of return to equities equals the risk-free rate. Risk aversion, however, implies that $r>\bar{e}$, so it is not valid to compare these instruments on the basis of their expected payoffs.

\subsubsection{Privatization Proposal}

Privatization begins at time $t=1$. Generation 0 agents, the current elderly, receive benefits under the current pay-as-you-go social security sys-

10. Smetters (1998) investigates the cost of guarantees in the presence of productivity shocks that affect wages, returns to capital, and returns to wage-indexed social security. Privatization tends to lead to even smaller reductions in unfunded liabilities in this context. 
tem. These benefits are paid for by generation 1 agents-new workerswho, in turn, receive nothing from social security. Instead, they face an additional new payroll tax,

$$
\tau^{N}=\frac{\psi \cdot \tau(1+g)}{(1+\bar{e})},
$$

which is used to finance the new privatized benefit. By construction, the benefit in the new private account, when invested in stocks, yields an $e x$ pected benefit equal to $\psi$ times the benefit provided under social security. I consider $\psi \geq 1$ here since no major privatization plan considers otherwise. The actual benefit can take any positive value greater than zero (owing to limited liability).

I assume that the government will wish to guarantee that a new account will replace some fraction $\chi$ of the benefit that an agent would have received under social security. A value of $\chi=1$ means that the new account yields a benefit at least equal to what an agent would receive under social security. This is a common benchmark. Some proposals to privatize the U.S. system, however, contemplate even more generous guarantees $(\chi>$ 1), so I will consider those values and smaller values.

Guarantees are financed on a pay-when-needed basis. Generation $t=$ 2 , therefore, bears the actuarial cost of the benefit guarantee given to generation $t=1$. Generations $t \geq 2$ do not face the social security payroll tax but instead face only the payroll tax $\tau^{N}$. Each generation receives a minimum-benefit guarantee from the next generation financed on a pay-whenneeded basis. The effect of privatization on the resources of each generation is outlined in Smetters (1998).

\subsubsection{Estimates of Guarantee Cost}

The government finances the guaranteed minimum benefit on a pay-asyou-go basis using payroll taxes. In Smetters (1998), I show that this fiscal policy is mathematically equivalent to an intergenerational transfer of put stock options, financed on a pay-as-you-go basis, that guarantee that these accounts produce the desired minimum benefit. ${ }^{11}$ The corresponding reduction in the ex ante value of unfunded liabilities in stochastic steady state (which incorporates changes in liabilities in the transition) for the more simple model presented in the current paper equals

$$
\left[1-\psi \cdot \frac{1+r}{1+\bar{e}} \cdot \hat{\Omega}\right] \cdot 100 \% .
$$

11. In the more complicated model considered by Smetters (1998), the strike price of the relevant option is wage indexed since the minimum benefit is tied to what a person would have received under social security (which is waged indexed). That paper also considered the case in which the guarantee is not waged indexed since, in reality, most countries that have implemented privatization have not waged indexed the benefit guarantee. 
The variable $\hat{\Omega}$ is the price of a one-period put option on a dollar's worth of equities with a strike price of $\$ 1[(\chi / \psi)(1+\bar{e})]$ next period. This strike price has a very intuitive interpretation. A higher expected-benefit level $(\psi)$, generated by a higher contribution rate $\tau^{N}$, lowers the implicit strike price provided that the guarantee level is not also increased. This is because more dollars are being contributed to the private accounts, and therefore each dollar need not perform as well for the same minimumbenefit guarantee to be satisfied. Similarly, a higher guarantee level $(\chi)$ effectively "raises the bar" and requires each dollar to perform better, which, in turn, increases the implicit strike price. The term $(1+r) /(1+\bar{e})$ effectively subtracts any attempt to arbitrage between the risk-free rate and the average return to equities.

The parameters in equation (6) are directly observable or can be computed using observable prices. The value of the put option can be priced exactly without any additional assumptions about the preferences beyond nonsatiation using the popular Black-Scholes (1973) option-pricing theorem. This is because the underlying price moments are assumed to fully incorporate all relevant information about preferences.

Table 3.1 reports values corresponding to equation (6) for various parameter choices. Following Feldstein and Samwick (1997), the annual average risk-free rate $(r)$ is set equal to 2 percent, and the economy's expected growth rate, $g$, is set equal to 1.1 percent per year. Bonds, therefore, are assumed to stochastically dominate social security. Privatization is compared against a solvent social security system's current-law benefits. This requires eventually increasing the payroll-tax rate to 18.75 percent. I also consider Feldstein and Samwick's choice of the average annual return to equities equal to 9 percent as one of the possible parameter values for $\bar{e}$. The standard deviation of the first differences of logged real returns on the S\&P500 equals 0.20 since 1928 and 0.164 since 1949 . I conservatively chose 0.16 in all calculations. Each period is assumed to represent thirty years, so the annual rates given above are converted to their thirty-year equivalents in all calculations presented here. ${ }^{12}$

Notice from table 3.1 that privatization with a large minimum-benefit guarantee has difficulty reducing unfunded liabilities. Consider the benchmark case $\psi=1$, in which the contribution rate to the new accounts is chosen to produce an expected benefit equal to the current social security benefit. This case was considered by Feldstein and Samwick (1997). The model presented here closely replicates their " 2 percent" contribution level, which they showed could be used to fully replace social security in the long run. ${ }^{13}$ Without a minimum-benefit guarantee, privatization would reduce the ex ante value of unfunded liabilities by 100 percent. Modifying

12. The choice of thirty years follows the two-period illustrative calculations presented in Feldstein and Samwick (1997).

13. Feldstein and Samwick were the first to note how well the two-period framework is able to produce tax rates that are comparable to their more elaborate multiperiod model. 
Table 3.1

New Contribution Rate for Private Account, $\tau^{N}$, Percentage Reduction in Unfunded Liabilities with a Minimum Benefit, Prefunding Tax Necessary to Eliminate Remaining Unfunded Liabilities, $\tau^{F}$ : Expected Retirement Income Equal to $\psi$ Times Social Security Coverage, Minimum Guaranteed Benefit Equal to $\chi$ Times Social Security Coverage, and Expected Return to Equities Equal to $\bar{e}$

\begin{tabular}{ccccccc}
\hline \multicolumn{3}{c}{$\begin{array}{c}\text { Exogenous } \\
\text { Parameters }\end{array}$} & \multicolumn{5}{c}{$\begin{array}{c}\text { Percent Reduction } \\
\text { in Unfunded } \\
\text { Liabilities }\end{array}$} & $\begin{array}{c}\text { Prefunding } \\
\text { Tax, } \tau^{F}\end{array}$ & $\begin{array}{c}\text { Value of Put Option, } \\
\hat{\Omega} \text {, per Dollar } \\
\text { Contribution (\$) }\end{array}$ \\
\hline 1 & $\chi$ & $\bar{e}$ & Tax Rate, $\tau^{N}$ & 21.1 & .1135 & 3.32 \\
1 & 1.00 & .07 & .0342 & 13.2 & .1248 & 6.36 \\
2 & 1.00 & .09 & .0196 & 31.6 & .0983 & 1.44 \\
2 & 1.00 & .07 & .0684 & 23.3 & .1103 & 2.81 \\
2 & 1.00 & .09 & .0392 & 10.7 & .1284 & 1.88 \\
2 & 1.25 & .07 & .0684 & -0.4 & .1442 & 3.68 \\
3 & 1.00 & .07 & .0392 & 35.4 & .0928 & .90 \\
3 & 1.00 & .09 & .0589 & 29.6 & .1012 & 1.72 \\
3 & 1.25 & .07 & .1026 & 17.1 & .1191 & 1.16 \\
3 & 1.25 & .09 & .0589 & 7.7 & .1326 & 2.25 \\
3 & 1.50 & .07 & .1026 & -2.5 & .1474 & 1.44 \\
3 & 1.50 & .09 & .0589 & -15.1 & .1654 & 2.81 \\
5 & 1.00 & .07 & .1710 & 36.4 & .0914 & .53 \\
5 & 1.00 & .09 & .0981 & 35.1 & .0933 & .95 \\
5 & 1.50 & .07 & .1710 & 3.9 & .1381 & .81 \\
5 & 1.50 & .09 & .0981 & -3.4 & .1486 & 1.51 \\
5 & 2.00 & .07 & .1710 & -31.9 & .1896 & 1.11 \\
5 & 2.00 & .09 & .0981 & -46.3 & .2102 & 2.14 \\
\hline
\end{tabular}

Note: Risk-free rate, $r$, equals 0.02 . Growth rate of tax base, $g$, equals 0.011 . Social security tax rate, $\tau$, equals 0.1875 . Length of each period equals 30 years.

their analysis to include a minimum-benefit guarantee, however, changes things dramatically. If the current social security benefit is guaranteed $(\chi$ $=1$ ), unfunded liabilities are now reduced by only 13 percent. One should not be surprised by this result. Using a payroll tax of only 2 percent to replace a payroll tax of 18.75 percent places a large demand on the equity premium that is unexploitable in the model presented here. Guaranteeing that this equity premium will, in fact, materialize places a large unfunded liability on future generations. Just how accurate is this calculation? Smetters (1998) shows that, in the special case of $\psi=\chi=1$, one can calculate the reduction in unfunded liabilities using an alternative procedure that does not rely on options pricing. ${ }^{14}$ The estimated reduction in unfunded liabilities is almost identical for both methods. 
Table 3.1 shows that, even at high contribution levels, privatization has a difficult time reducing unfunded liabilities. Consider, for example, $\psi=$ 3 , where the expected private benefit is three times the social security benefit. The contribution level equals 6 percent of payroll, but unfunded liabilities are reduced by only 30 percent at $\chi=1$. For $\psi=5$, the contribution level is about 10 percent, but the reduction in unfunded liabilities is only 35 percent. Even at $\psi=8$ (not shown), privatization reduces unfunded liabilities by only 36 percent even though the contribution rate is now almost 16 percent. A higher contribution level reduces how well each contributed dollar must perform in order for the sum of dollars in a private account to satisfy the minimum benefit. This is shown by the smaller value of $\hat{\Omega}$ in table 3.1 associated with higher contribution rates. A higher contribution level, however, requires insuring a larger number of dollars. The net effect on unfunded liabilities associated with increasing the contribution level is minimal. So, for example, at $\psi=\chi=1$, the price of the implicit put option per dollar of contribution equals $\$ 6.36$ with a strike of $\$ 13.27$. Increasing the contribution level by five times (so that $\psi=5$ ) reduces the value of the put option to only $\$ 0.95$ since the strike price is now only $\$ 2.65$ (i.e., one-fifth of \$13.27). So the sheer number of dollars being insured is now five times greater than before, but the value of the put option per invested dollar decreases by only six and a half times, resulting in only a small net decrease in the unfunded liability.

Note that the "oversaving strategy" associated with high contribution levels is not the same thing as diversification. Diversification is a powerful risk-management technique because it pools assets whose returns are not perfectly correlated. In sharp contrast, a larger contribution level simply throws in more dollars, and the return to each additional dollar is perfectly correlated with the last dollar contributed. The fundamental problem with the oversaving strategy is that it fails to make the intergenerational side payments that are necessary to significantly reduce unfunded obligations. In Smetters (1998), I show that these side payments are an automatic feature of prefunding a defined-benefit system. Since the current paper, however, is about privatization, I consider an alternative technique, which I call a prefunding guarantee tax.

Table 3.1 shows the value of a hypothetical prefunding tax from current to future workers that would fully eliminate all unfunded liabilities remaining after privatization:

$$
\tau^{F}=\frac{\psi \cdot \tau(1+g)}{(1+\bar{e})} \cdot \hat{\Omega} / Y_{1}=\hat{\Omega} \cdot \tau^{N} .
$$

are passed to future generations. This would be the case if, e.g., the government were attempting to prefund the current defined-benefit system. The verification works very well in this case. Moreover, for the one-sided bet with $\psi=\chi=1$, the ex ante value of the unfunded liabilities passed to future generations is very close to the value for the two-sided bet. The reason is that the upside potential has very little value in this case. 
New Contribution Rate for Private Account, $\tau^{N}$, Percentage Reduction in Unfunded Liabilities with a Minimum Benefit, Prefunding Tax Necessary to Eliminate Remaining Unfunded Liabilities, $\tau^{F}$ : Expected Retirement Income Equal to $\psi$ Times Social Security Coverage, Minimum Guaranteed Benefit Equal to 0.75 Times Social Security Coverage, and Expected Return to Equities Equal to $\bar{e}$

\begin{tabular}{|c|c|c|c|c|c|c|}
\hline \multicolumn{3}{|c|}{$\begin{array}{l}\text { Exogenous } \\
\text { Parameters }\end{array}$} & \multirow{2}{*}{$\begin{array}{l}\text { New Payroll } \\
\text { Tax Rate, } \tau^{N}\end{array}$} & \multirow{2}{*}{$\begin{array}{l}\text { Percent Reduction } \\
\text { in Unfunded } \\
\text { Liabilities }\end{array}$} & \multirow{2}{*}{$\begin{array}{l}\text { Prefunding } \\
\quad \text { Tax, } \tau^{F}\end{array}$} & \multirow{2}{*}{$\begin{array}{c}\text { Value of Put Option, } \\
\hat{\Omega}, \text { per Dollar } \\
\text { Contribution }(\$)\end{array}$} \\
\hline$\psi$ & $x$ & $\bar{e}$ & & & & \\
\hline 1 & .75 & .07 & .0342 & 44.3 & .0801 & 2.34 \\
\hline 1 & .75 & .09 & .0196 & 37.7 & .0895 & 4.56 \\
\hline 2 & .75 & .07 & .0684 & 51.0 & .0705 & 1.03 \\
\hline 2 & .75 & .09 & .0392 & 45.9 & .0778 & 1.98 \\
\hline 3 & .75 & .07 & .1026 & 52.3 & .0686 & .67 \\
\hline 3 & .75 & .09 & .0589 & 49.9 & .0720 & 1.22 \\
\hline 5 & .75 & .07 & .1710 & 52.3 & .0686 & .40 \\
\hline 5 & .75 & .09 & .0981 & 52.2 & .0687 & .70 \\
\hline
\end{tabular}

Note: Risk-free rate, $r$, equals 0.02 . Growth rate of tax base, $g$, equals 0.011 . Social security tax rate, $\tau$, equals 0.1875 . Length of each period equals 30 years.

This tax would have to be used to increase public saving (i.e., instead of spending it elsewhere). In practice, this tax could be used to reduce the level of baseline debt or, for example, other pay-as-you-go liabilities associated with Medicare; a surplus would have to be invested in the capital market. Equation (7) has a straightforward interpretation: it says that full self-insurance requires current workers to purchase a put option themselves for each dollar that they invest in their new accounts via the new payroll tax, $\tau^{N}$. Anything less would pass some insurance cost to future generations, who, by assumption, cannot credibly commit to provide a minimum benefit less than $\chi$ times current social security coverage. A tax equal to $\tau^{F}$, therefore, eliminates all remaining unfunded liabilities after privatization.

Table 3.1 shows that, for the policy parameters $\{\psi, \chi\}$, a total tax rate $\left(\tau^{N}+\tau^{F}\right)$ of 14.5 percent is needed to fully eliminate all unfunded liabilities. The total tax rate for the policy parameters $\{\psi, \chi\}=\{5,1\}$ is over 19 percent. The reason for the large difference is that, in the case $\{\psi, \chi\}=$ $\{1,1\}$, the size of the guarantee funding tax, $\tau^{F}$, equals 12.5 percent, which is larger than the 9.3 percent tax for $\{\psi, \chi\}=\{5,1\}$. Because more revenue is transferred to future generations in the case $\{\psi, \chi\}=\{1,1\}$, it requires a smaller overall tax rate to fully eliminate all unfunded liabilities.

Table 3.2 shows the effects of reducing the guarantee level to 75 percent of the benefit provided by social security. Consider the case $\{\psi, \chi\}=\{1$, $0.75\}$. Whereas privatization reduced unfunded liabilities by only 13 percent with a 100 percent guarantee, it now reduces unfunded liabilities by 
38 percent with a 2 percent contribution level. Including a funding tax of 9 percent, for a total of 11 percent, fully eliminates all unfunded liabilities.

\subsection{Conclusion}

This paper shows that high guarantees can be quite costly. But it would be wrong to interpret these results as suggesting that a move toward personalized accounts must be a bad idea. This paper is about pay-whenneeded guarantees. Although pay-when-needed guarantees appear to be cheap because they cost nothing up front, they can be quite costly from a risk-adjusted perspective. The balancing act facing privatizers is to select a modest guarantee level that is also credible over time. Alternatively, privatization could be accompanied with a generous guarantee that is prefunded with a prefunding tax from current workers to future workers.

\section{References}

Black, F., and M. J. Scholes. 1973. The pricing of options and corporate liabilities. Journal of Political Economy 81, no. 3:637-54.

Bodie, Z. 1995. On the risk of stocks in the long run. Financial Analysts Journal 55, no. 3 (May/June): 18-22.

Bodie, Z., and D. B. Crane. 1998. The design and production of new retirement savings products. Harvard Business School. Working Paper no. 98-070.

Bohn, Henning. 1998. Risk sharing in a stochastic overlapping generations economy. University of California, Santa Barbara, January. Mimeo.

Campbell, John, and Robert Shiller. 1998. Valuation ratios and the long-run stock market outlook. Journal of Portfolio Management 24, no. 2 (winter): 11-26.

Diamond, Peter, and Salvador Valdés-Prieto. 1994. Social security reforms. In The Chilean economy: Policy lessons and challenges, ed. Barry P. Bosworth, Rudiger Dornbusch, and Raúl Labán. Washington, D.C.: Brookings.

Feldstein, Martin, and Andrew Samwick. 1997. The economics of prefunding social security and medicare benefits. In NBER macroeconomics annual 1997, ed. Ben S. Bernanke and Julio Rotemberg, 115-48. Cambridge, Mass.: MIT Press.

Goetzmann, William, N., and Philippe Jorion. 1996. Global stock markets in the twentieth century. Yale School of Management/University of California at Irvine. Mimeo.

Gramm, Phil. 1998. Investment-based social security. U.S. Senate, Washington, D.C. Circulated mimeo.

Hieger, Melissa, and William Shipman. 1997. Common objections to a marketbased social security: A response. The Cato Project on Social Security Privatization, SSP no. 10. 22 July. Available at http:/www.socialsecurity.org/pubs/ssps/ sspstudies.html.

Jagannathan, Ravi, and Narayana Kocherlakota. 1996. Why should older people invest less in stocks than younger people? Federal Reserve Bank of Minneapolis Quarterly Review 20, no. 3 (summer): 11-23.

Kocherlakota, Narayana R. 1996. The equity premium: It's still a puzzle. Journal of Economic Literature 34, no. 1:42-71. 
Marcus, Alan J. 1987. Corporate pension policy and the value of PBGC insurance. In Issues in pension economics, ed. Zvi Bodie, John B. Shoven, and David A. Wise. Chicago: University of Chicago Press.

Mehra, Rajnish, and Edward Prescott. 1985. The equity premium: A puzzle. Journal of Monetary Economics 15, no. 2:145-61.

Merton, Robert. 1973. Theory of rational option pricing. Bell Journal of Economics 4 , no. 1 (spring): 141-83.

-1983. On the role of social security as a means for efficient risk sharing in an economy where human capital is not tradable. In Financial aspects of the United States pension system, ed. Zvi Bodie and John B. Shoven. Chicago: University of Chicago Press.

. 1998. Applications of option-pricing theory: Twenty-five years later. American Economic Review 88, no. 3 (June): 323-49.

Mitchell, Olivia, and Flavio Ataliba Barreto. 1997. After Chile, what? Secondround pension reforms in Latin America. NBER Working Paper no. 6316. Cambridge, Mass.: National Bureau of Economic Research.

Ross, Stephen A. 1976. The arbitrage theory of capital asset pricing. Journal of Economic Theory 13, no. 3:341-60.

Shiller, Robert J. 1996. Price-earnings ratios as forecasters of returns: The stock market outlook in 1996. Department of Economics, Yale University. Mimeo.

Shipman, William. 1998. Facts and fantasies about transition costs. The Cato Project on Social Security Privatization, SSP no. 13. October. Available at http:// www.socialsecurity.org/pubs/spss/sspstudies.html.

Smetters, Kent. 1998. Privatizing versus prefunding social security. University of Pennsylvania. Mimeo.

\section{Comment David W. Wilcox}

A number of plans for the privatization of social security propose to guarantee that beneficiaries receive a specified minimum amount irrespective of how financial markets may perform. A guarantee of this type transfers to the government part of the risk associated with uncertain future rates of return. This fine paper by Kent Smetters notes that such a guarantee generally represents an unfunded liability of the new system and argues that this liability may be very large —indeed, possibly nearly as large as the unfunded liability associated with the current system.

The central result in Smetter's paper runs as follows: if beneficiaries are guaranteed at least their current-law benefit, and if the payroll-tax rate is set so as to generate the current-law benefit assuming that stocks yield 9 percent year in and year out, then the unfunded liability associated with the benefit guarantee is about 87 percent as large as the unfunded liability in the current system. Moreover, a strategy of "oversaving" turns out to

David W. Wilcox is assistant secretary for economic policy in the U.S. Department of the Treasury.

The views expressed in this Comment are those of the author and are not the official views of the Treasury Department. 
be relatively ineffective in reducing the unfunded liability associated with the benefit guarantee: even if the payroll tax rate is set at five times the level required to generate the current-law benefit in expectation, the unfunded liability associated with the benefit guarantee is still 65 percent as large as the unfunded liability in the current system.

In chapter 2 in this volume, Feldstein, Ranguelova, and Samwick (FRS) also examine the potential cost of benefit guarantees. They estimate that the probability of the guarantee becoming binding could plausibly be designed to be quite low. And, even in the event that the guarantee is binding, they estimate that the cost in most cases would be relatively modest. Overall, FRS believe the financial burden of benefit guarantees to be manageable: "The remaining moderate level of retiree risk [of a benefit that is lower than under current law, taking into account the higher expected return on financial assets] can be completely eliminated by a government guarantee that can be provided with very little risk to taxpayers."

It could be that both papers are correct. Smetters could be correct that financial markets would place a very high price on a benefit guarantee of the type he studies, possibly because the required payment in rare cases would be very large, possibly because the circumstances in which the payment is required are precisely the circumstances in which taxpayers are especially unhappy about providing it. FRS could simultaneously be correct that the government will need to make good on a well-designed benefit guarantee with only low probability and that the required payment will in most cases be small.

Notwithstanding that both papers could be correct, they differ in two important respects. First, Smetters relies on the fundamental validity of observed securities prices as reflections of informed decisions of rational agents with sensible degrees of risk aversion, even if we economists cannot write down a simple model that explains all aspects of these data. In particular, Smetters treats the equity premium as reflecting compensation for risk and not as "a costless exploitable opportunity" for the government. By contrast, FRS question the wisdom of grounding decisions about government policy in data that we cannot fully understand or explain, save perhaps by appeal to an implausible assumption about the degree of risk aversion in financial markets. (In the context of a standard representativeagent model with isoelastic utility, the observed equity premium can be explained only by assuming an implausibly large coefficient of relative risk aversion.)

A second important dimension along which the two papers differ is the metric they use to assess the cost of a guarantee. FRS adopt a frequentist perspective (Smetters calls it the likelihood approach) and provide information about tail probabilities and the shape of distributions associated with investment outcomes. By contrast, Smetters views the issue through the prism of financial market prices that should embed all the FRS infor- 
mation about tail probabilities but should as well incorporate information about preferences and covariances with consumption.

In principle, there is no inherent conflict between these two approaches; they simply provide different information about the same question. Smetters evaluates the cost of a benefit guarantee at market prices. Presumably, this is a useful approach if one believes that government policies should be evaluated assuming that the price of risk is the same to the government as it is to private transactors in financial markets. By contrast, FRS provide some of the raw material that one would need to assemble in order to evaluate the cost of a benefit guarantee under the assumption that the government should be willing to transact as a risk-neutral agent. ${ }^{1}$ All other differences between the two papers aside, one can obviously arrive at different conclusions about the desirability of a given policy depending on the price one attaches to the financial risk that may be involved in that policy.

The issue of whether risk-related aspects of government policies should be evaluated at market prices crops up in a surprising number of contexts in the practical policy-making arena. Some of these instances arise out of the budget "scorekeeping" process. By way of background, both the Congressional Budget Office and the Office of Management and Budget have important responsibilities in estimating the cost of legislative proposals moving through the Congress. The current state of the art in this area is to assign, in effect, a zero price to risk - or, to put it slightly differently, to assume that the government operates as a risk-neutral agent.

A recent instance arises in the context of the student loan program. Under current law, payments to lenders under this program are indexed to the Treasury-bill rate. On a number of occasions, Congress has considered proposals to shift the index to something more closely approximating the cost of funds to lenders in this market - perhaps the commercial paper rate or LIBOR. A move along these lines would reduce lenders' so-called basis risk (the risk associated with fluctuations in the spread between their borrowing and their lending rates). However, the government would take on a similar risk because it would still be borrowing at the Treasury-bill rate but would begin making payments indexed to some private-sector rate. Current budgetary scorekeeping practice would take account of such factors as average spreads between Treasury and private rates but would effectively assign a budgetary cost of zero to any basis risk assumed by the government. Swap markets, on the other hand, take quite a different view of the price of risk.

A separate set of questions pertains to the plausibility of Smetters's estimates. Of necessity, his model is of course highly stylized. Which omitted

1. I say some rather than all because FRS do not provide a complete mapping of tail probabilities and tail shapes. 
features might bias his estimate of the cost of a guarantee, and in which direction? First, as Smetters notes, his model provides no discretion in the choice of a portfolio - either within the realm of equity investments (e.g., small cap vs. large cap) or in the larger design of the portfolio (e.g., whether to have any equity exposure at all). Even in the absence of moral hazard, any flexibility in portfolio choice will drive up the cost of a benefit guarantee (because the government would be left holding the downside of any available choice while beneficiaries would reap the upside), so long as the rates of return on the available alternatives are not perfectly correlated. And moral hazard would drive up the cost still further.

Second, because the agents in Smetters's model work only one period, there is no heterogeneity in the timing of earnings. In the real world, two workers who accumulate an identical entitlement to social security benefits may have quite different profiles of earnings and hence may have experienced quite different exposure to the stock market. Again, heterogeneity of this type will tend to push up the cost of a guarantee.

Third, because the agents in Smetters's model live only one period in retirement, there is no need for annuitization. In the real world, the policy process may choose to impose a requirement for annuitization in order to protect beneficiaries from outliving their social security wealth. The rate at which account balances are annuitized represents another source of financial risk, quite distinct from the pattern of equity returns, and hence another source of upward push to the actual cost of a guarantee.

The paper by Smetters touches on fundamental issues in the debate about social security reform. What makes that paper even more interesting is the productive dialogue in which it engages with the work of FRS. The social security reform process will be the beneficiary of this productive interchange.

\section{Discussion Summary}

Stephen Ross wondered why the equity-risk premium enters the analysis, given that it is being called an arbitrage-pricing approach. In particular, he asked why the equity-risk premium plays any role in deciding what the values of the current benefits are under any alternative plan. Kent Smetters responded that the experiments in this paper, as in others, are being done by choosing a payroll tax such that the expected benefit of the new system is equal to the benefit that would have been received under social security. The equity-risk premium affects the choice of the payroll tax. Put differently, one is trying to exploit the wedge between $\bar{e}$, the expected rate of return on equities, and $g$, the return that social security would have given. 
Effectively, the results suggest that this wedge cannot be exploited in the case of risk adjustment.

Ross concluded that using the term arbitrage in the context of the paper might be misleading as the analysis does use a utility-based model. Deborah Lucas concurred.

Robert King raised the issue that option prices generated by the BlackScholes formula are independent of the equity premium. Smetters replied that, although the equity premium does not explicitly appear in the formula, it does matter through the strike price chosen.

Martin Feldstein emphasized that this entire discussion is a very fundamental issue and encouraged subsequent discussions about the role of the equity premium in the social security reform debate.

James Poterba inquired why Smetters did not consider looking at the market price of long-term options on a broad index of stocks in order to gauge the cost of obtaining a truncated distribution of returns, similar to the one implicit in a benefit guarantee. Depending on one's view of the Arrow-Lind theorem, an interesting alternative for using the tax system to redistribute the risk of a shortfall is to have financial market participants bear it. The issue at the core of the debate is which arrangement bears this risk in the most efficient way.

Zvi Bodie remarked that such options are traded only for maturities up to three years. Longer-maturity instruments are available only over the counter.

John Shoven noted that it could be argued that both Smetters and Feldstein, Ranguelova, and Samwick probably set themselves too high a goal in their papers as the current social security system does not provide a benefit guarantee either. He wondered whether it was not too ambitious to try to replace the current system with one that is far superior in terms of benefit guarantees.

In a similar vein, Feldstein asked Smetters to point out what reduction in unfunded liabilities would correspond to a scenario where the guarantee $(\chi)$ equals 75 percent rather than 100 percent. He noted that the results across the rows in table 3.1 looked roughly linear and symmetrical and wondered whether it was therefore correct to infer from rows 3 and 5 that the reduction in unfunded liabilities would be in the 50 percent range for $\chi$ equal to 75 percent. Smetters confirmed this.

With reference to Poterba's question, Antonio Rangel remarked that, even if the market were cheaper than the tax system in bearing the risk of a shortfall, it would not yield full efficiency in an intergenerational context.

Henning Bohn noted that the pricing approach in this paper assumes complete markets. This standard assumption might not be valid in the context of the paper because future unborn generations, currently not exposed to equity risk, might not assess the same price for the bailout of a cohort in the event of a shortfall as the generation currently alive would. 
This issue relates to the potential imperfection in risk sharing from an ex ante perspective in overlapping-generations models. The shadow value of receiving a certain guarantee might be different across different cohorts.

Andrew Samwick asked Smetters to clarify the difference between his setup and the one in the Feldstein, Ranguelova, and Samwick paper. In particular, row 2 of table 3.1 shows a payroll tax $\tau^{N}$ of around 2 percent and a reverse pay-as-you-go tax $\tau^{R}$ of 12.4 percent. Although these numbers are quite similar to some of the exercises reported in Feldstein, Ranguelova, and Samwick, the results are not. The discussant, David Wilcox, pointed out that there is a third tax, not reported in the table, which is the tax on the current generation to bear the unfunded liability of the current system.

John Campbell stated that he wanted to follow up on Bohn's remark. Some models of the equity premium emphasize constraints faced by the young. For instance, Constantinides, Donaldson, and Mehra (1998) explain the equity premium by imposing borrowing constraints on the young. They have a substantial amount of human capital and would like to borrow to invest in equities, but they cannot. This rationalizes a high equity premium. In that context, a government system that in effect relaxes the constraint by using the taxing power of the government would affect asset prices. This possibility is excluded by Smetters's assumption of fixed market prices.

Smetters stated that the portfolio choice is restricted and that this ignores potential sources of moral hazard. Not doing so would increase the unfunded liabilities. Also, the focus of the paper is on a two-period model, which eliminates some sources of risk, as Wilcox noted. Enriching the model with either of these features would be an interesting extension.

With respect to Poterba's remark, Smetters stated that he initially examined market data for two-year options on a broad stock index. He found that these are overpriced by the market, according to the Black-Scholes formula. Moreover, the Arrow-Lind theorem assumes orthogonality, which is not the case in the model of the paper.

Smetters agreed with Shoven's comment that the current system does not completely commit to paying out the promised benefits.

Regarding incomplete markets, Smetters made two points. First, it is not obvious to tell from current models whether hedging is cheaper for the government than for private agents in the case of incomplete markets. Second, even if it were cheaper for the government so that there would be some arbitrage surpluses, the costs in the paper are to be interpreted as opportunity-cost calculations. In other words, if these surpluses did exist, they could be used for other purposes as well.

Finally, Smetters agreed with Campbell that the introduction of fric- 
tions, for instance, borrowing constraints, would have important implications for this line of research.

\section{Reference}

Constantinides, George, John Donaldson, and Rajnish Mehra. 1998. Junior can't borrow: A new perspective on the equity premium puzzle. NBER Working Paper no. 6617. Cambridge, Mass.: National Bureau of Economic Research. 
